\title{
Influence of Al Particle Size and Firing Profile on Void Formation in Rear Local Contacts of Silicon Solar Cells
}

\author{
Katharina Dressler, Martina Kratt, Philipp A. Voss, Stefanie Ebert, Axel Herguth, and Giso Hahn
}

\begin{abstract}
In this paper, the influence of Al particle size and the applied firing profile on void formation in local rear contacts of wafer-based silicon solar cells is investigated. Samples with a passivated emitter and rear cell (PERC) rear, but without front metallization, were metalized with six different Al screen-printing pastes, i.e., both commercial and homemade, featuring different particle size distributions and fired in a rapid thermal processing furnace with different firing profiles. Voids were detected with scanning acoustic microscopy measurements, and the fraction of voids in rear local contacts was analyzed. It was shown that the heating phase of the firing process has the strongest influence on void formation. With slower heating, void formation could be reduced to a fraction lower than $5 \%$ of the local contact area. Furthermore, it was shown that Al pastes consisting of a mixture of small and large Al particle sizes have a positive effect on the formation of voids.
\end{abstract}

Index Terms-Crystalline silicon, firing, particle size, passivated emitter and rear cell (PERC), solar cells, voids.

\section{INTRODUCTION}

$\mathbf{T}$ HE passivated emitter and rear cell (PERC) concept for silicon solar cells, first proposed by Blakers et al. in 1989 [1], is regarded as the next evolutionary step in large volume silicon solar cell production and is already being introduced in large-scale manufacturing. By adding a dielectric passivation layer on the solar cell rear side and a local opening of this layer before metallization to form only local aluminum/silicon $(\mathrm{Al} / \mathrm{Si})$ contacts, cell efficiencies up to $21.4 \%$, on large-area $\left(15.6 \times 15.6 \mathrm{~cm}^{2}\right)$ Czochralski $(\mathrm{CZ})$ monocrystalline (mono) $\mathrm{Si}$ solar cells, have been reached [2].

During heating and the peak temperature of the firing process, the $\mathrm{Al}$ in the $\mathrm{Al}$ paste diffuses to the local contacts, where $\mathrm{Si}$ is dissolved into the liquid $\mathrm{Al} / \mathrm{Si}$ alloy. The dissolved Si diffuses in the opposite direction out of the contacts. During cooling, $\mathrm{Si}$ diffuses back to the contacts, where a strongly $\mathrm{Al}$ doped region recrystallizes. The actual metallic contacts beyond are filled

K. Dressler, M. Kratt, S. Ebert, A. Herguth, and G. Hahn are with the University of Konstanz, 78457 Konstanz, Germany (e-mail: katharina.dressler@unikonstanz.de; martina.kratt@uni-konstanz.de; stefanie.riegel@uni-konstanz. de; axel.herguth@uni-konstanz.de; giso.hahn@uni-konstanz.de).

P. A. Voss is with the Centre for Organismal Studies, Heidelberg University, 69120 Heidelberg, Germany(e-mail: philipp.voss@cos.uni-heidelberg.de). with the remaining solidified $\mathrm{Al} / \mathrm{Si}$ eutectic [3], [4]. The step in dopant density between recrystallized region and p-doped base results in the build-up of a (local) back surface field (BSF) repelling electrons, thus passivating the contact to a certain degree.

Frequently, a formation of voids in local rear contacts is observed [5], [6] resulting in some cases in a non-BSF passivated local contact or no local contact to the rear-side metallization at all. One of the hypotheses regarding void formation is that voids are formed due to the Kirkendall effect [7]. Si diffuses much faster into the $\mathrm{Al} / \mathrm{Si}$ alloy (through the necks between sintered $\mathrm{Al}$ particles) than $\mathrm{Al}$ diffuses in the opposite direction toward the local contacts. As the cooling is very fast $(\sim 5 \mathrm{~s})$, it may occur that Si solidifies as lamellas in the Al particles, instead of recrystallizing in the local contact area, and voids are formed [5]. To avoid void formation due to a lack of Si during rapid cooling, there are several approaches. The addition of $\mathrm{Si}$ has already shown good results [8], [9]. In addition, the optimization of the contact spacing or firing with the $\mathrm{Al}$ paste on top was tested [10], [11]. Another approach is an adaption of the firing profile, like heating-up in several steps, to reduce the driving force of the Si diffusion due to the gradient of Si concentration on the $\mathrm{Al} / \mathrm{Si}$ interface [12] or the broadening of the firing profile by reducing the belt speed with an additional lowering of the peak temperature, which also lowers the diffusion of $\mathrm{Si}$ [13]. A further possibility is to extend the cooling above $577^{\circ} \mathrm{C}$ (eutectic solidification temperature) to ensure that the time for Si to diffuse back to the local contacts is long enough.

In this study, variations of heating and cooling time, both separate and combined, are carried out to see which phase of the firing process has the main influence on void formation.

As the size of the $\mathrm{Al}$ particles can have an influence on $\mathrm{Si}$ diffusion during the firing process [14], the influence of $\mathrm{Al}$ particle size on the void formation is also investigated.

\section{EXPERIMENTAL DETAILS}

For the firing variation, $5 \times 5 \mathrm{~cm}^{2}$ mono-CZ Si wafers with an as-cut wafer thickness of 180-200 $\mu \mathrm{m}$ were used. The samples were alkaline textured and received a homogeneous $60-\Omega / \square$ phosphorous emitter formed by a $\mathrm{POCl}_{3}$-based tube furnace diffusion step. The emitter on the rear side and edge was removed by wet chemical edge isolation. The front-side emitter is covered with a silicon nitride antireflective coating and the rear surface with a standard dielectric passivation stack, consisting of a thin aluminum oxide layer capped with a silicon nitride layer, both deposited in a plasma-enhanced chemical vapor deposition 
TABLE I

AL Particle Size Distribution for the DifFERENT AL PASTES

\begin{tabular}{lcccccc}
\hline \hline Group & A & B & C & D & E & F \\
\hline $\mathrm{D}_{10}[\mu \mathrm{m}]^{1}$ & Between C \& D & 1.5 & 1.9 & 2.2 & 4.0 & $1: 1$ mix of B \& D \\
$\mathrm{D}_{50}[\mu \mathrm{m}]$ & & 2.6 & 4.1 & 5.1 & 8.2 & \\
$\mathrm{D}_{90}[\mu \mathrm{m}]$ & & 4.2 & 10.4 & 13.1 & 16.3 & \\
\hline \hline
\end{tabular}
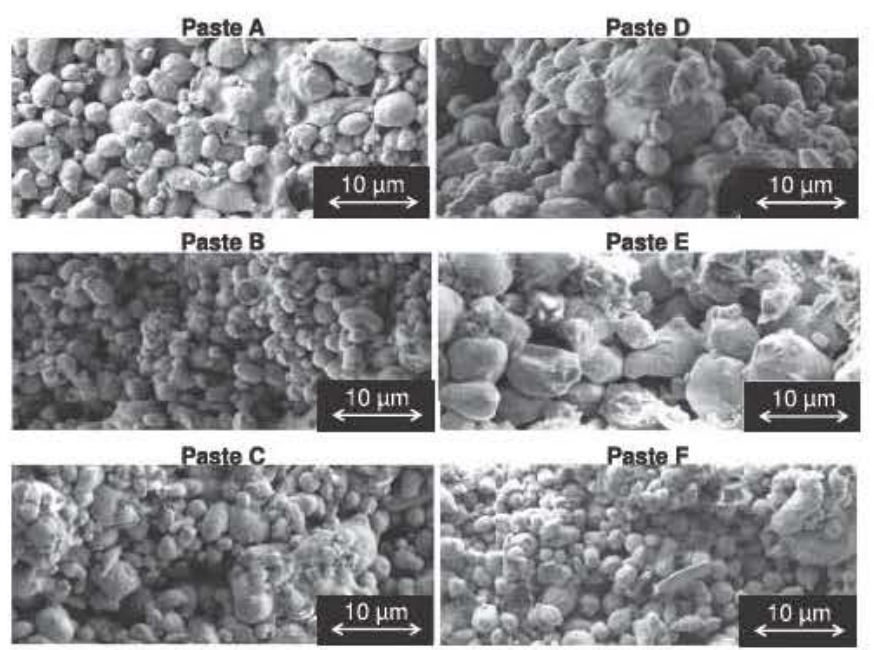

Fig. 1. SEM images of tested $\mathrm{Al}$ pastes, where the paste identifications are above related images.

system. The line-shaped rear contact openings are formed by laser ablation [15] with a width of $20 \mu \mathrm{m}$ and a pitch of $1 \mathrm{~mm}$. The rear side is metalized with six different Al PERC pastes. Group A was metalized with a commercial Al PERC paste, which is known for a good contact formation, although a lot of voids are formed to clearly see the influence of the temperature profiles. Groups B-F were metalized with homemade $\mathrm{Al}$ pastes. Pastes B-E differ in Al particle size distribution (see Table I ), Paste $F$ was a mixture of pastes B and D and was tested after characterization of pastes A-E. Scanning electron microscopy (SEM) images of the tested $\mathrm{Al}$ pastes are shown in Fig. 1.

The four $\mathrm{Al}$ powders were provided by the same supplier to eliminate differences caused by different manufacturing processes. The homemade $\mathrm{Al}$ pastes consist of the $\mathrm{Al}$ powder, a glass frit made for PERC-type solar cells, binder, and solvent.

The firing variation was made in a rapid thermal processing (RTP) furnace (XREACT, Xerion). First, a firing profile similar to a standard firing furnace profile was generated. The profile has a small plateau at $550{ }^{\circ} \mathrm{C}$ and a peak temperature of ca. $800{ }^{\circ} \mathrm{C}$, measured on the sample. The heating (after the plateau at $550^{\circ} \mathrm{C}$ till $\left.800{ }^{\circ} \mathrm{C}\right)$ and cooling time $\left(800^{\circ} \mathrm{C}\right.$ till the eutectic temperature $577^{\circ} \mathrm{C}$ ), is around $5 \mathrm{~s}$. This firing profile was optimized on solar cells, metalized with the commercial PERC paste A, and was applied for all pastes. With this paste, efficiencies of $19.8 \%$ and fill factors of $77.8 \%$ were achieved on large-area $\mathrm{Cz}$ wafers $(6 \mathrm{in})$ in a parallel experiment.

Within the first experiment, the cooling was extended only. Five firing profiles with different cooling times of $8,12,18,25$,

${ }^{1} D_{X}<Y: X \%$ of the particles have a diameter smaller than $Y$.

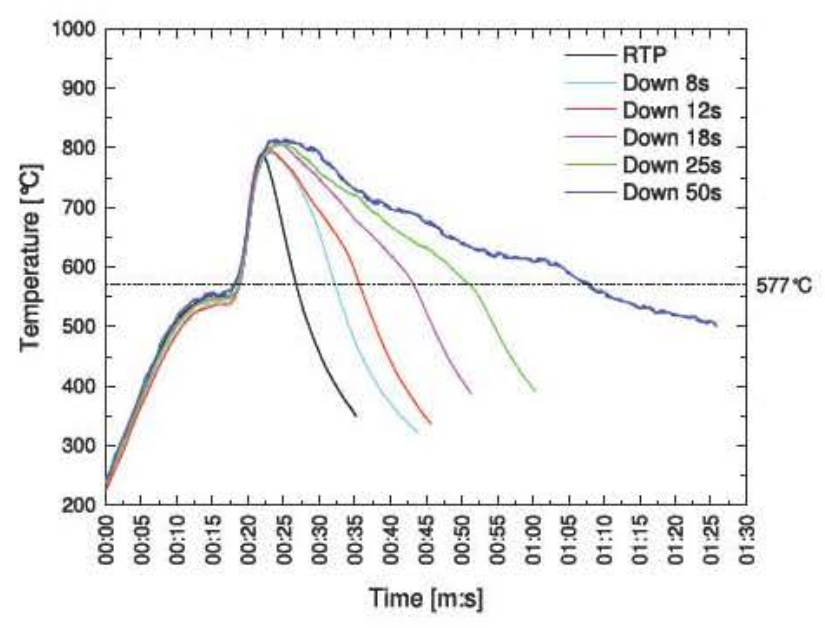

Fig. 2. RTP firing profiles with different cooling times.

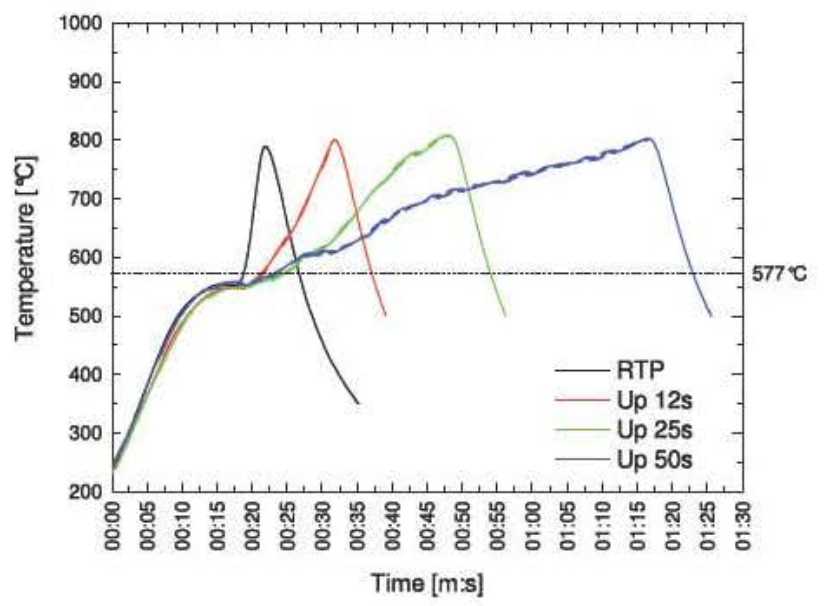

Fig. 3. RTP firing profiles with different heating times.

and $50 \mathrm{~s}$ were generated (see Fig. 2; called "Down X s" in the following).

For the second experiment, firing profiles with extended heating times (see Fig. 3; called "Up X s") and combined firing profiles with both extended heating and cooling (called "Combined $\mathrm{X}$ s") were generated. For these profiles, only three different times were used: 12,25 , and $50 \mathrm{~s}$.

For all firing variations, the temperature profile up to the plateau at $550^{\circ} \mathrm{C}$ and the peak temperature of $800{ }^{\circ} \mathrm{C}$ were not changed. The temperature measurement for the generation of the profiles was made on samples identical to the description above, but without metallization. The thermocouple was glued on the sample with thermal conductive adhesive.

The formation of voids in local rear contacts was characterized with a scanning acoustic microscope (SAM) (V400, KSI) [16], [17]. As voids show up as dark lines in SAM images, the total length of the voids is measured, and the proportion of the total void length, compared with the total contact length, is calculated.

For further characterization of the influence of $\mathrm{Al}$ particle size on void formation, the Si diffusion out of the local contacts was measured. As the dissolved Si darkens the paste, this can be measured by means of optical microscope images. The width of 


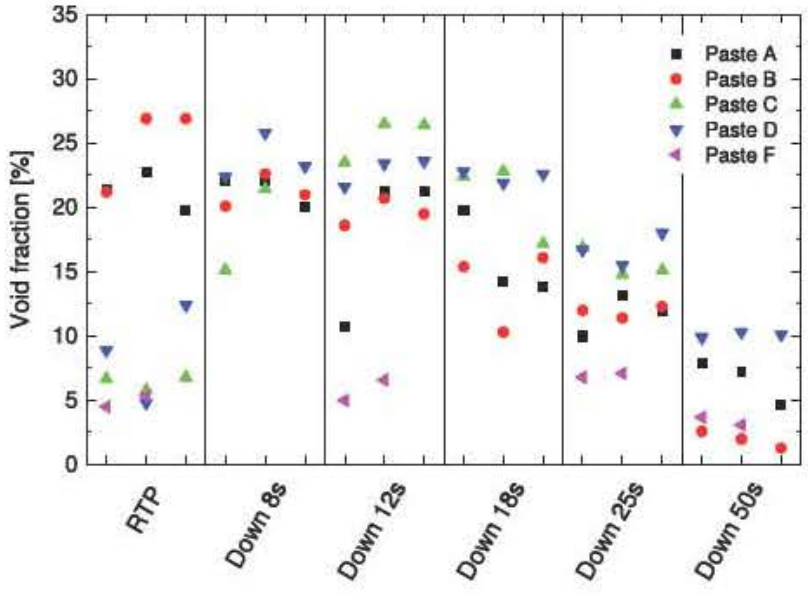

Fig. 4. Void fraction determined on three samples in each group metalized with $\mathrm{Al}$ pastes $\mathrm{A}-\mathrm{D}$ and $\mathrm{F}$ after firing with extended cooling.

the darkened $\mathrm{Al}$ paste is called the maximum spread limit of $\mathrm{Si}$ in the $\mathrm{Al}$ paste [5].

Subsequently, the paste particles and the eutectic layers were etched off in hydrochloric acid solution, and the depth of the local contacts, not considering the remaining BSF, was measured, also using optical microscope images.

\section{Results}

In the first experiment, the cooling was extended. Fig. 4 shows the void fractions of pastes A-D and F. Samples metalized with reference paste $\mathrm{A}$ have maximum void fraction applying the standard firing profile, and void fraction decreases with increasing cooling times. Samples metalized with paste B, which is the paste containing the smallest $\mathrm{Al}$ particles, show the same behavior with increasing cooling times.

With pastes $\mathrm{C}$ and $\mathrm{D}$, the void fraction is low when using the standard firing profile. With longer cooling times, the void fraction strongly increases at first. For longer cool-down times, the void fraction decreases, but it remains larger than for the RTP standard firing profile.

To get a better understanding of these differences in void formation, the maximum spread distance of diffused $\mathrm{Si}$ in the $\mathrm{Al}$ paste after firing was measured, and optical microscope images of the local contacts, after etching the $\mathrm{Al}$ paste, were analyzed.

The measured maximum spread distance (see Fig. 5) increases with longer cooling times for all pastes, but it is conspicuous that the smallest spread distance of $\mathrm{Si}$ in the $\mathrm{Al}$ paste occurs with paste $\mathrm{C}$. For longer cooling times, especially for a cooling time of $50 \mathrm{~s}$, the darkening due to out-diffused $\mathrm{Si}$ from adjacent contact lines overlaps so that a maximum spread distance is no longer quantifiable.

Analyzing the average contact depth after etching the paste shows that paste $\mathrm{C}$ again shows the lowest values (see Fig. 6). The average contact depth and the narrow Si distribution for paste $\mathrm{C}$ could be a hint that with the used firing profiles, this paste could not form a contact that is good enough for PERC cells. Because of this, further analysis was made without this paste.

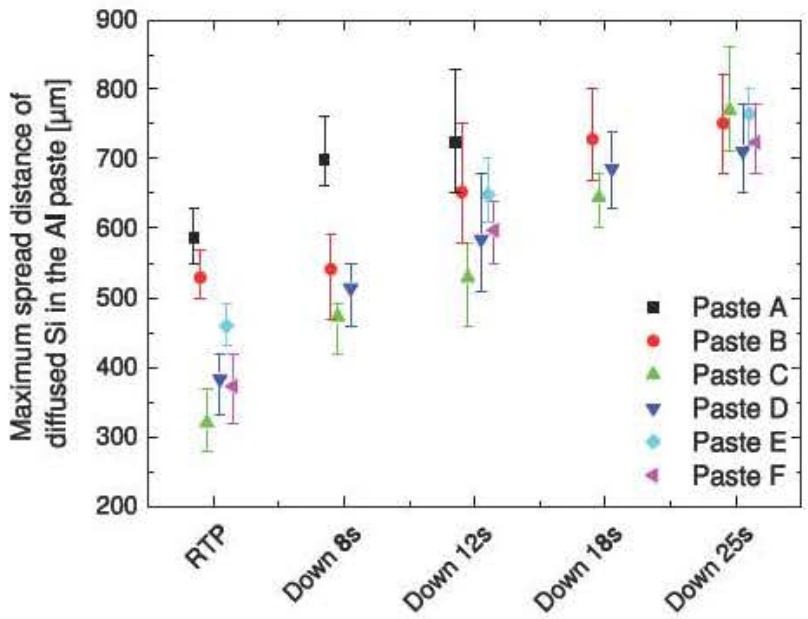

Fig. 5. Maximum spread distance of diffused $\mathrm{Si}$ in the Al pastes after firing with different cooling times. Each of the three points resembles a SAM measurement of a complete sample.

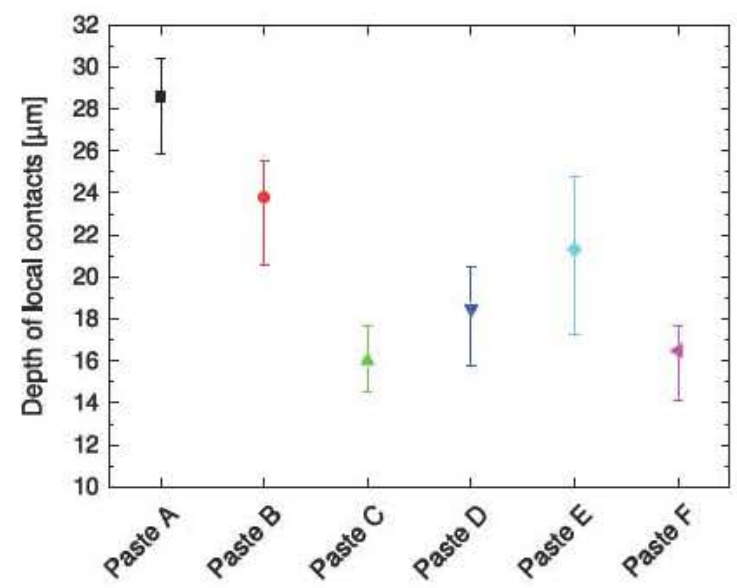

Fig. 6. Average depth of local contacts after firing in the RTP furnace with standard profile, measured with an optical microscope after etching of the Al paste. For each value, five to seven measurements, respectively, on two to three samples per profile, were made.

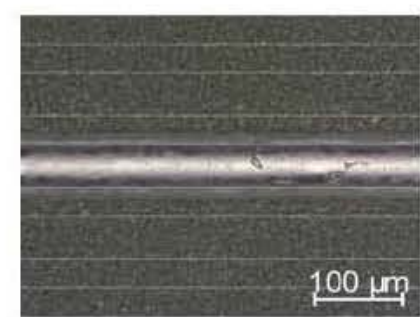

(a)

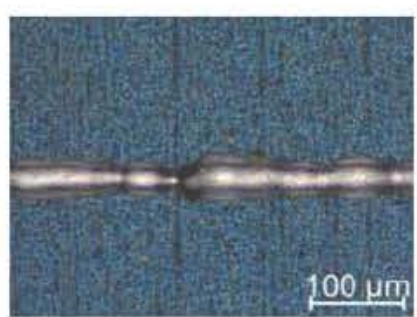

(b)
Fig. 7. Optical microscope images of local contacts after firing and removing metallization (a) paste A and (b) paste E, RTP standard firing profile). The local contacts with paste $\mathrm{E}$ are very thin and show lots of necks. For each profile, about nine measurements were made (three samples per paste and three measurements per sample).

Paste E was also excluded from further experiments, because it showed problems in contact formation. Optical microscope images showed that the line-shaped contacts were relatively thin and had a lot of neckings (see Fig. 7). Furthermore, the measurements of the void formation via SAM showed no clear results for paste $\mathrm{E}$ because the contrast in the images was not 


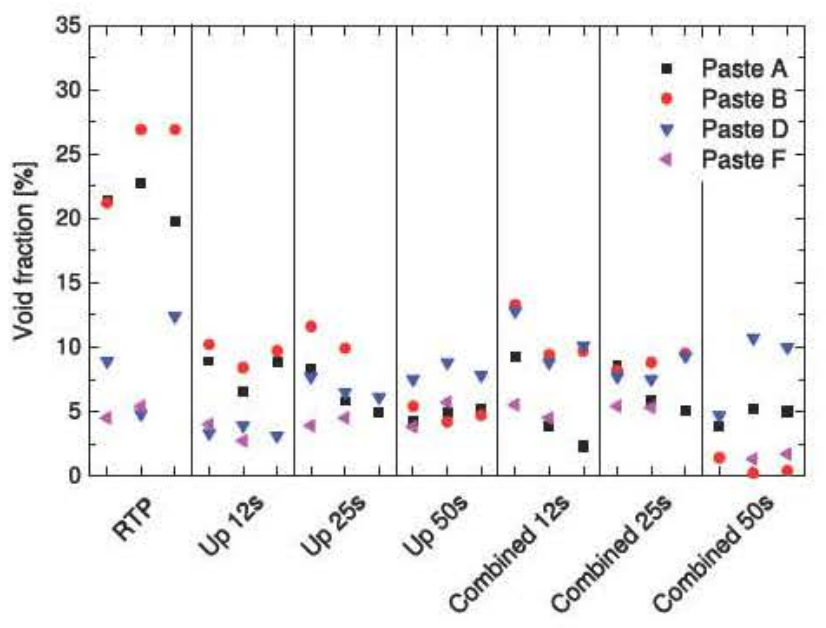

Fig. 8. Void fraction of tested Al pastes after firing with extended heating time and combined profiles with both extended heating and cooling times.

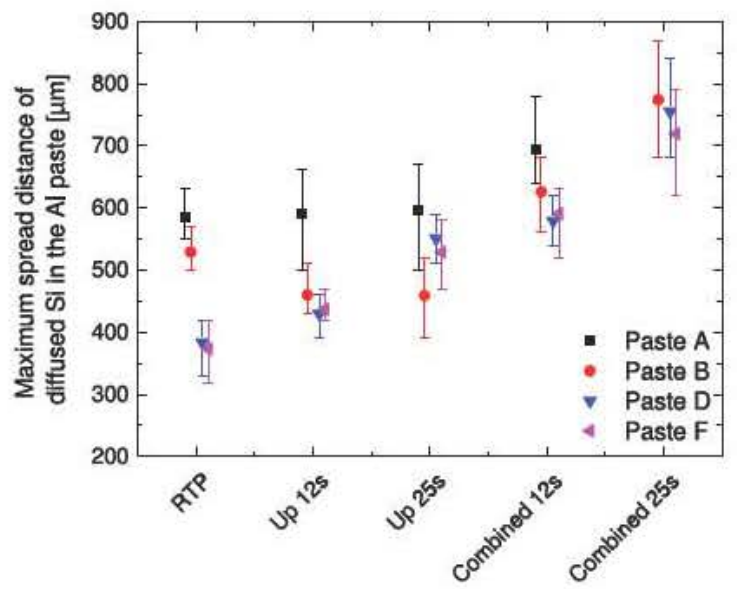

Fig. 9. Maximum spread distance of diffused $\mathrm{Si}$ in the $\mathrm{Al}$ pastes after firing with extended heating time and combined profiles with both extended heating and cooling times.

sufficient for reliable void detection. Therefore, the void fraction with paste $\mathrm{E}$ is not shown in Fig. 4. The low contrast in the SAM images might be caused by the large $\mathrm{Al}$ particles, which form empty cavities in between the individual particles, thus enhancing the scattering of incoming sound waves.

Paste F was made of a mixture of pastes B and D to get a dense distribution of $\mathrm{Al}$ particles. This paste shows a very small void fraction that is independent of cooling times.

It is conspicuous that for an appreciable reduction in void fraction, except for paste $\mathrm{F}$, cooling times over $25 \mathrm{~s}$ are needed. Therefore, in the second experiment, profiles with extended heating times and combined profiles were tested to see which part of the firing profile has the strongest influence on void formation (see Fig. 8).

It is quite obvious that with these profiles, void fractions are explicitly smaller than with only slower cooling. Again, the void fraction is lowest with paste F. In Fig. 9, the maximum spread distance of $\mathrm{Si}$ in the $\mathrm{Al}$ paste after firing is shown. One can see that in addition, with these profiles, Si diffuses generally farther with longer firing profiles.

\section{DISCUSSION}

\section{A. Influence of Firing Profile}

As void formation is strongly linked to Si diffusion, the hypothesis was that a longer cooling time is beneficial with regard to void reduction caused by the Kirkendall effect. With only short cooling times, Si may solidify in the paste instead of inside the local contacts. However, the first experiment shows that the cooling has only a moderate influence on the formation of voids, or at least very long cooling times, i.e., above $25 \mathrm{~s}$, are needed to significantly reduce the void fraction. One reason for this behavior could be that also during cooling, $\mathrm{Si}$ is dissolved and diffuses further away from the local contact. In addition, as expected, the measurement of the maximum spread distance of the diffused $\mathrm{Si}$ in the $\mathrm{Al}$ paste after firing shows that with longer cooling times, the maximum spread distance increases.

Further experiments show that extended heating times have the largest influence on the formation of voids. One reason might indeed be a reduced driving force of Si diffusion [12]. By slowing down both the heating and the cooling time, the influence on void formation is nearly the same, as with slower heating only. This also shows that the influence of the cooling is very small and that the Kirkendall effect is not the main reason for void formation.

\section{B. Influence of Al Particle Size}

The comparison of different $\mathrm{Al}$ particle sizes shows no clear results. During the firing process, for the most part, the cores of the $\mathrm{Al}$ particles melt, and the shells remain stable. Diffusion occurs with the help of necks between the particles [3]. In pastes with mainly very small particles, on the one hand, diffusion should be slower, as more diffusion necks per unit length have to be formed, and each neck acts as a bottleneck hindering diffusion, while the unhampered diffusion distance in the particles is comparably short. On the other hand, smaller particles are prone to form denser networks and might offer a more direct way for lateral diffusion of $\mathrm{Si}$ in the pastes. When the particle size increases, there are less diffusion necks to form per unit length, and the unhampered diffusion distance within the particles increases. Diffusion should, therefore, become faster. However, empty spaces between the particles increase with bigger particles; thus, lateral diffusion of $\mathrm{Si}$ in the paste follows rather a zigzag line, which counteracts a faster diffusion.

To simultaneously benefit from the faster diffusion in bigger particles and avoid empty spaces, it is helpful to mix smaller and bigger particles. The results of paste $\mathrm{F}$, which is a mixture of pastes $\mathrm{B}$ and $\mathrm{D}$, shows the minimum void formation, which is independent of the used firing profile.

\section{CONCLUSION}

Within this work, for the first time, RTP studies on the influences of different phases of the firing profile (heating and cooling) on the formation of voids have been carried out in a systematic way. It could be shown that the heating time has the main influence. By extending this phase of the firing process, the proportion of voids can be reduced significantly. In contrast, 
extending the cooling phase has only a small influence. This could be seen on the results of the extended cooling, as well as on the results of the combined profiles. With different cooling times, a clear reduction of the void fraction cannot be seen until cooling times of $25 \mathrm{~s}$. The results of combined profiles (prolonged heating and cooling) do not significantly differ from the prolonged heating profiles, also indicating that there is only small influence of cooling on void formation.

With different Al particle sizes, there are several influences on $\mathrm{Si}$ diffusion in the $\mathrm{Al}$ paste. In pastes with smaller $\mathrm{Al}$ particles, a lot of diffusion necks have to be formed, and the diffusion distances in the particles are short; indeed, there are only a few empty spaces between the particles. In pastes with larger Al particles, the diffusion distance inside the particles is longer, and not so many necks have to be formed, but there could be empty spaces between the particles. Therefore, the mixture of different particle sizes benefits the reduction of void formation.

\section{ACKNOWLEDGMENT}

K. Dressler would like to thank her former colleagues at SCHOTT Solar for the excellent collaboration. She also thanks S. Fritz for etching the samples.

\section{REFERENCES}

[1] A. W. Blakers, A. Wang, A. M. Milene, J. Zhao, and M. A. Green, "22.8\% efficient silicon solar cell," Appl. Phys. Lett., vol. 55, no. 13, pp. $1363-1365,1989$.

[2] P. J. Verlinden et al., "Challenges and opportunities of high-performance solar cells and PV modules in large volume production," presented at the 42th IEEE Photovoltaic Spec. Conf., New Orleans, LA, USA, Jun. 14-19, 2015.

[3] F. Huster, "Investigation of the alloying process of screen printed aluminium pastes for the BSF formation on silicon solar cells," in Proc. 20th Eur. Photovoltaic Sol. Energy Conf. Exhib., 2005, pp. 1466-1469.

[4] F. Grasso, L. Gautero, J. Rentsch, R. Preu, and R. Lanzafame, "Characterization of aluminum screen-printed local contacts," in Proc. 2nd Workshop Metallization Crystalline Silicon Sol. Cells, 2010, pp. 15-21.

[5] E. Urrejola, K. Peter, H. Plagwitz, and G. Schubert, "Silicon diffusion in aluminum for rear passivated solar cells," Appl. Phys. Lett., vol. 98, art. no. $153508,2011$.

[6] T. Lauermann, A. Zuschlag, S. Scholz, G. Hahn, and B. Terheiden, "The influence of contact geometry and sub contact passivation on the performance of screen printed $\mathrm{Al}_{2} \mathrm{O}_{3}$ passivated solar cells," in Proc. 26th Eur. Photovoltaic Sol. Energy Conf. Exhib., 2011, pp. 1137-1143.

[7] E. O. Kirkendall, "Diffusion of zinc in alpha brass," Trans. AIME, vol. 147, pp. 104-109, 1942.

[8] V. Meemongkolkiat et al., "Investigation of modified screen-printing Al pastes for local back surface field formation," in Proc. IEEE 4th World Conf. Photovoltaic Energy Convers., 2006, pp. 1338-1341.

[9] M. Rauer et al., "Aluminium alloying in local contact areas on dielectrically passivated rear surfaces of silicon solar cells," IEEE Electron Device Lett., vol. 32, no. 7, pp. 916-918, Jul. 2011.

[10] E. Urrejola, K. Peter, H. Plagwitz, and G. Schubert, "Distribution of silicon in the aluminum matrix for rear passivated solar cells," Energy Procedia, vol. 8, pp. 331-336, 2011.

[11] E. Urrejola, K. Peter, H. Plagwitz, and G. Schubert, "Effect of gravity on the microstructure of Al-Si alloy for rear-passivated solar cells," J. Appl. Phys., vol. 110, no. 5, art. no. 056104, 2011.

[12] D. Chen et al., "Preventing the formation of voids in the rear local contact areas for industrial-type PERC solar cells," in Proc. 28th Eur. Photovoltaic Sol. Energy Conf. Exhib., 2013, pp. 770-774.

[13] T. Fang, C.-M. Lin, K.-J. Li, L.-T. Wang, and W.-C. Tang, "Metallization of rear-side passivated cells: Reducing cavities on local contacts," in Proc. 26th Eur. Photovoltaic Sol. Energy Conf. Exhib., 2011, pp. 2220-2222.
[14] M. Balucani et al., "Aluminum-Silicon interdiffusion in screen printed metal contacts for silicon based solar cells applications," Energy Procedia, vol. 43, pp. 100-110, 2013.

[15] Y. Gassenbauer et al., "Rear surface passivation technology for crystalline silicon solar cells: A versatile process for mass production," IEEE J. Photovoltaics, vol. 3, no. 1, pp. 125-130, Jan. 2013.

[16] K. Dressler et al., "Characterization of rear local contacts including BSF formation using Raman and scanning acoustic microscopy," in Proc. 27th Eur. Photovoltaic Sol. Energy Conf. Exhib., 2012, pp. 755-758.

[17] K. Dressler et al., "Nondestructive characterization of voids in rear local contacts of PERC-type solar cells," IEEE J. Photovoltaics, vol. 5, no. 1, pp. 70-76, Jan. 2015.

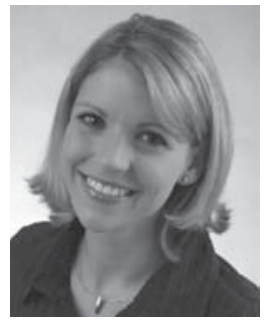

Katharina Dressler received the Diploma degree in electrical engineering from the Aschaffenburg University of Applied Sciences, Aschaffenburg, Germany, in 2009. She is currently working toward the $\mathrm{Ph} . \mathrm{D}$. degree in physics with the Technische Universität Bergakademie Freiberg, Freiberg, Germany.

From 2009 to 2012, she was a Development Engineer for the Schott Solar Ag in the metallization group. Her focus was the rear-side metallization of passivated emitter and rear cell (PERC)-type solar cells. From 2013 to 2015, she was with the Photovoltaics Division, University of Konstanz, also studying PERC metallization.

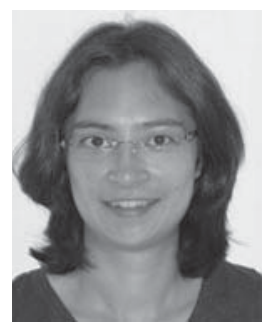

Martina Kratt received the M.Sc. degree in physics from the University of Konstanz, Konstanz, Germany in 2014, having done her research project in the area of nanooptics/laser physics.

In 2015, she was a Graduate Research Assistant with the Photovoltaics Division, University of Konstanz, developing an image processing program for void analysis of silicon solar cells based on scanning acoustic microscopy measurements.

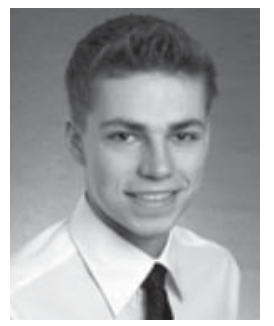

Philipp A. Voss received the M.Sc. degree in life science from the University of Konstanz, Konstanz, Germany, in 2014. He is currently working toward the Ph.D. degree in biology with Heidelberg University, Heidelberg, Germany.

From 2014 to 2015, he was a Graduate Research Assistant with the Photovoltaics Division, University of Konstanz, creating firing profiles for the rapid thermal processing furnace.

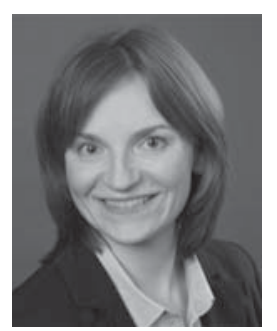

Stefanie Ebert received her final exam (Staatsexamen) in physics and mathematics from the RuprechtKarls-Universität Heidelberg, Heidelberg, Germany, in 2006. She is currently working toward the Ph.D. degree with the Photovoltaics Division, University of Konstanz, Konstanz, Germany.

Her research interests include screen-printed metallization and contact formation of crystalline silicon solar cells. 


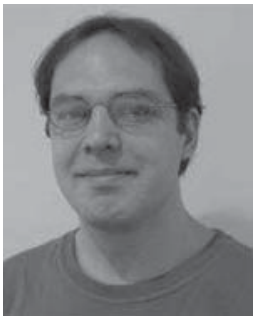

Axel Herguth received the Diploma degree in physics from the University of Konstanz, Konstanz, Germany, in 2006.

Since 2007, he has been the Head of the characterization group with the Photovoltaics Division, University of Konstanz. His research interests include the kinetics of defects in silicon in general and, especially, the kinetic of the metastable boron-oxygenrelated defect, as well as characterization techniques for silicon wafers and solar cells.

Mr. Herguth received the Junior Einstein Award from Solarworld in 2006 for his work on the avoidance of the boron-oxygenrelated degradation.

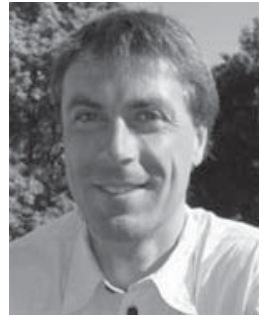

Giso Hahn received the Ph.D. degree in physics from the University of Konstanz, Konstanz, Germany, in 1999.

Since 2009, he has been a Professor with the Department of Physics, University of Konstanz, where he is the Head of the Photovoltaics Division, which is focused on crystalline silicon materials and solar cell process development. His research interests include the characterization of promising low-cost materials for photovoltaic applications and the development of adapted solar cell processes for these and other materials. $\mathrm{He}$ is a Member of the scientific committees of various conference series and workshops. Among other scientific and technological achievements, his group is interested in transferring technologies from the laboratory stage to industry. 